\title{
TOŻSAMOŚCIOWY WYMIAR WSPÓŁPRACY TRANSGRANICZNEJ POLSKI I UKRAINY. Z BADAŃ NAD ŚWIADOMOŚCIA ZBIOROWA MIESZKAŃCÓW OBSZARÓW PRZYGRANICZNYCH
}

\author{
IDENTITY DIMENSION OF CROSS-BORDER \\ COOPERATION BETWEEN POLAND AND UKRAINE: \\ RESEARCH ON THE COLLECTIVE CONSCIOUSNESS \\ OF INHABITANTS OF BORDER AREAS
}

Tomasz Peciakowski • , Wojciech Gizicki

\begin{abstract}
ABSTRAKT
Artykuł ukazuje współpracę transgraniczną między Polską i Ukrainą z perspektywy mikrospołecznej, podkreślającej wymiar tożsamościowy kontaktów społecznych i ich konsekwencje. W przeprowadzonych w grudniu 2019 r. badaniach wśród mieszkańców obszarów przygranicznych Polski i Ukrainy zwrócono uwagę na to, czy współpraca ta stała się wśród mieszkańców terenów przygranicznych ważną perspektywą postrzegania sąsiedzkich relacji, jak mocno wyrażana jest potrzeba jej rozwoju oraz jak postrzegane są jej efekty.

W świadomości badanych dominuje perspektywa postrzegania transgranicznych relacji polsko-ukraińskich jako opartych na kontaktach
\end{abstract}

The article shows cross-border cooperation between Poland and Ukraine from a micro-social perspective. It emphasizes the identity dimension of social contacts and their consequences. The research from December 2019 among the inhabitants of the border areas of Poland and Ukraine was concerned with whether this cooperation has become an important perspective for the perception of neighborly relations among the inhabitants of border areas, how strongly the need for its development is expressed and how its effects are perceived.

The respondents perceive cross-border Polish-Ukrainian relations through the prism of economic contacts. The consciousness of

* Katolicki Uniwersytet Lubelski Jana Pawła II w Lublinie, Instytut Nauk Socjologicznych.

** Katolicki Uniwersytet Lubelski Jana Pawła II w Lublinie, Instytut Nauk o Polityce i Administracji. 
ekonomicznych. Zakorzeniona jest też świadomość asymetrii regionalnych, co wpływa na różnice w postrzeganiu współpracy transgranicznej między mieszkańcami terenów przygranicznych. Mimo różnic badani zwracali uwagę na elementy kulturowe łączące oba narody oraz walory ułatwiające komunikację.

Słowa kluczowe: Polska; Ukraina; współpraca transgraniczna; tereny przygraniczne; tożsamość; świadomość zbiorowa regional asymmetries influences the differences in the perception of cross-border cooperation between the inhabitants of border areas. Despite this, the respondents paid attention to the cultural elements linking both nations and the values facilitating communication.

Keywords: Poland; Ukraine; cross-border cooperation; border areas; identity; collective consciousness

\section{WPROWADZENIE}

Obszar przygraniczny łączący Polskę z Ukrainą to wyjątkowy teren, wymagający szczególnego zainteresowania, zarówno ze strony badaczy, jak i polityków. Nie ma drugiej takiej lądowej granicy w Europie, która - według danych Banku Światowego (World Bank Database, 2019) - dzieliłaby kraje o większej różnicy (względnej) w dochodzie PKB per capita niż ta pomiędzy Polską a Ukrainą. Szereg analiz (Rosik, Goliszek, Duma, Komornicki, 2020; Buller, Kotarski, Pachkovskyy, 2017; Jakubowski, Bronisz, Miszczuk, 2017; Jakubowski, Miszczuk, Kawałko, Komornicki, Szul, 2016) pozwala na stwierdzenie, że trudno odnaleźć na kontynencie europejskim inne tereny przygraniczne $\mathrm{z}$ tak dużymi dysproporcjami. Ponadto tereny po obu stronach granicy należą do słabiej rozwiniętych regionów swoich państw, w związku z czym najintensywniejsze międzynarodowe powiązania powstają najczęściej z dala od granicy. Rodzi to bardzo poważne konsekwencje (Buller i in., 2017; Miszczuk, 2017; Osikowicz, 2017) na wielu poziomach, którym władze - od regionalnych przez rządowe po unijne - starają się przeciwdziałać, m.in. poprzez stymulowanie na tym obszarze współpracy transgranicznej. Wspomaga ona redukowanie dysproporcji i niwelowanie społecznych napięć, będąc jednocześnie platformą dla dyfuzji innowacji gospodarczych, przepływów kulturowych i wzajemnych inspiracji. Według założeń współpraca między społecznościami ponad granicami jest jednym z kluczowych czynników rozwoju regionalnego obszarów przygranicznych (Svenson, 2015; Sousa, 2013).

Współpraca transgraniczna na pograniczu polsko-ukraińskim ma dziś więc znaczenie strategiczne dla obu sąsiedzkich krajów, a także całej Unii Europejskiej, bowiem obszary sąsiadujących regionów obu państw tworzą jednocześnie część zewnętrznej, wschodniej granicy UE. Z jednej strony ustanawia to dodatkowe 
bariery dla ruchu granicznego, pogłębia asymetrię systemów gospodarczych i politycznych, z drugiej stwarza to szanse dla obu stron na zdobycie środków, wykorzystanie potencjału i przyśpieszenie rozwoju opartego m.in. o współprace międzyregionalną. Ta jednak najczęściej wiąże się z kontaktami pomiędzy podmiotami zbiorowymi: instytucjami, firmami i organizacjami. Tymczasem za parawanem umów o współpracy, realizowanych projektów partnerskich, transakcji handlowych i wielu innych działań transgranicznych znajdują się mieszkańcy terenów przygranicznych, przygodni turyści, lokalni handlarze, pracownicy regionalnych instytucji publicznych. Osoby często przekraczające granicę patrzą na ruch graniczny i wzajemne relacje obu graniczących ze sobą krajów i społeczeństw z bardzo osobliwej perspektywy. Zdaniem niektórych badaczy (Levy, Peiperl, Bouquet, 2013; Boman, Berg, 2007) kluczowe dla właściwego rozwoju współpracy transgranicznej i transnarodowego kapitału społecznego, będącego produktem tej współpracy - poza zrozumiałą instytucjonalizacją relacji między podmiotami zbiorowymi po obu stronach granicy - jest budowanie transgranicznej tożsamości. Bierze się ona z poczucia przynależności do określonego terytorium - stykowego wobec innej kultury i poddawanego silnemu oddziaływaniu pobliskiej granicy. Tożsamość ta wyrasta z codzienności, w której transgraniczność można rozumieć jako zespół praktyk stosowanych w obszarach przygranicznych, tworzących relacje transnarodowe. Współpraca transgraniczna rozgrywa się więc poprzez dwie „transgraniczne siły” (Rybicka, 2016, s. 26) - administracyjną i społeczną.

Celem artykułu jest ukazanie współpracy transgranicznej między Polską i Ukrainą z perspektywy mikrospołecznej, podkreślającej wymiar tożsamościowy kontaktów społecznych i ich konsekwencje. Chodzi o weryfikację, na ile współpraca ta stała się wśród mieszkańców terenów przygranicznych ważną perspektywą postrzegania sąsiedzkich relacji. W przeprowadzonych w grudniu $2019 \mathrm{r}$. badaniach wśród mieszkańców obszarów przygranicznych Polski i Ukrainy główna uwaga zwrócona została na to, jak mocno wyrażana jest potrzeba rozwoju współpracy transgranicznej oraz jaki jej obraz konstruowany jest w świadomości respondentów: czy badani zauważają efekty współpracy transgranicznej, w jakich obszarach i poprzez jakiego typu kontakty współpraca ta rozwija się, ich zdaniem, najlepiej, co stanowi zagrożenie, a co szansę na dalszy jej rozwój. Badania zostały przeprowadzone na obszarze przygranicznym, gdzie stykają się Województwo Lubelskie oraz Obwód Wołyński, wchodzące w skład Euroregionu Bug - jest to teren, który wyraźnie intensyfikuje powyżej wskazywane cechy wschodniej granicy Unii Europejskiej. 


\section{WSPÓŁPRACA TRANSGRANICZNA A TOŻSAMOŚCI POGRANICZA}

Granica państwa spełnia kilka funkcji: jest linią przestrzenną oddzielającą terytorium podmiotów politycznych, państw lub terytoriów bez jednoznacznej suwerenności, ale jest także linią podziału o wielowymiarowym znaczeniu gospodarczym, społecznym i kulturowym (Otok, 2006; Rykiel, 2005). Współcześnie rola granic w kontekście relacji transgranicznych ulega intensywnym przemianom. Następuje powolne zanikanie barier przestrzennych, choć jest to proces, który odbywa się punktowo i w sposób zróżnicowany sektorowo. Przekraczanie granicy w celu zrobienia zakupów, zatankowania samochodu nie musi od razu oznaczać przekraczania jej w celach podjęcia współpracy gospodarczej lub korzystania z usług edukacyjnych czy zdrowotnych (Komornicki, Wiśniewski, 2017). Dlatego strefa Schengen nie tyle zlikwidowała granice, co zmieniła ich funkcje - stały się strefą transgranicznych kontaktów, miejscem przepływów towarów i osób, w którym zniknęły bariery przemieszczania się, ale pojawiły się inne (np. na płaszczyźnie gospodarczej lub społecznej) (Sparke, 2006). I choć zupełnie inną specyfiką charakteryzują się obszary tworzące zewnętrzną granicę Unii Europejskiej, gdzie mocno sformalizowane procedury przekraczania potęgują bariery między sąsiadami, to istniejące tam problemy wynikają nie tylko $\mathrm{z}$ formalnych przeszkód o charakterze prawnym. Często o wiele większe wyzwanie stanowią bariery o charakterze ekonomicznym, społecznym i kulturowym. Stąd też samo eliminowanie formalnych i technicznych trudności związanych z przekraczaniem granic państwowych, choć bardzo ważne, nie spowoduje nagle wygaśnięcia negatywnych skutków istnienia granicy (Böhm, Opioła, Drosik, 2019).

W Europie - już na poziomie oficjalnych dokumentów - zwraca się na to uwagę od przeszło 40 lat (by wspomnieć chociażby tzw. Konwencję Madrycką Rady Europy z 21 maja 1980 r., Europejską Kartę Samorządu Terytorialnego z 15 października 1985 r. oraz początek Europejskiej Współpracy Terytorialnej /Interreg/ z 1990 r.). W konsekwencji na tradycyjne mapy twardych granic państwowych w Europie nałożyć można dzisiaj kartograficzne wizualizacje Euroregionów - przygranicznych obszarów o zinstytucjonalizowanej współpracy transgranicznej, dążącej do umocnienia i rozwoju sąsiedzkich relacji między społecznościami przedzielonymi granicą państwową. Euroregiony jako obszary o wciąż sztucznej i słabej - jak przystało na „regiony z papieru” (Paasi, 2001, s. 14) - identyfikacji są powoływane w nadziei, że w niedalekiej przyszłości staną się zarzewiem nowej lokalnej tożsamości, będąc ważnym punktem odniesienia 
w życiu codziennym lokalnych wspólnot - „regions as social practice” (Paasi, 2001, s. 14).

Współpracę transgraniczną opisuje się często z perspektywy relacji podmiotów zbiorowych - organizacji, samorządów, firm, publicznej administracji - a jej ocena zależna jest od liczby powiązań między podmiotami po obu stronach granicy, ulokowanych środków, inwestycji infrastrukturalnych etc. (Dołzbłasz, 2017; Osikowicz, 2017). Tyle że instytucjonalizacja relacji transgranicznych to tylko jeden z wymiarów tej współpracy (Böhmi inn., 2019; Svensson, 2015; Levy i in., 2013), odnosi ona względny sukces dopiero wtedy, gdy zauważalna jest zdolność kształtowania praktyk, zbudowanie stałych, a nie incydentalnych relacji instytucjonalnej współpracy. Powinna być więc zakorzeniona w społecznej świadomości, w zindywidualizowanych próbach budowania transgranicznych relacji. Za kluczowe dla rozwoju transgranicznych więzi należy bowiem uznać dwa procesy jako odbicia dwóch wymiarów transnarodowego kapitału społecznego (Levy i inn., 2013; Boman, Berg, 2007): instytucjonalizację współpracy między podmiotami zbiorowymi oraz budowanie transgranicznej tożsamości, opartej przede wszystkim o kapitał społeczny typu pomostowego (bridging) (Putnam, 2000), wyrażający się poprzez ustanowione sieci relacji, określoną wspólnotę norm i wartości oraz wzajemne zaufanie.

Kształtowanie się tego typu kapitału społecznego w wymiarze transnarodowym opiera się na tożsamościach granicznych lokalnych mieszkańców, którzy zaczynają tworzyć wspólną tożsamość w ramach koncepcji nowego regionu (Wong Villanueva, Kidokoro, Seta, 2020; Paasi, 2001). Znajduje to odzwierciedlenie w świadomości społecznej mieszkańców obszarów przygranicznych i stopniowym przyswajaniu przez nich dopiero co powstałych transgranicznych (w tym przestrzenno-czasowych) możliwości. Pomimo częstych rozbieżności interesów, wewnątrzkrajowych przepisów i regulacji, wielu barier integracyjnych, poczucie przynależności do kulturowej wspólnoty pogranicza, historycznie wpisanych interakcji (choć nie zawsze pozytywnych) i wspólne zrozumienie własnych potrzeb, zachęcają ich do zawiązywania wielu formalnych i nieformalnych relacji współpracy na szczeblu regionalnym i lokalnym (Wong Villanueva i in., 2020). Oczywiście powstaje w tym miejscu ważne pytanie, czy w celu zbudowania nowego podziału ponad granicami tworzyć odgórnie regiony, dopiero rozpoczynając tym samym identyfikowanie się z nimi lokalnych mieszkańców, czy też wykorzystać tylko te obszary, w których istnieje już pewna świadomość regionalna (Ramutsindela, 2013). Przed tym dylematem stają nie raz decydenci zarządzający geopolityczną przestrzenią, bowiem stymulowanie tożsamości 
transgranicznych jest dzisiaj ważnym narzędziem polityki. Tożsamość jest wówczas rozumiana jako „miękkie” narzędzie, używane przez władze na całym świecie do promowania spójności społecznej, marketingu regionalnego i rozwoju gospodarczego (Paasi, 2009). Stąd też nadzieja władzy politycznej, że kształtowanie na danych obszarach przygranicznych tożsamości transgranicznej pomaga zwiększyć zaufanie graniczących ze sobą wspólnot, wzmaga relacje między nimi i zwiększa skuteczność praktyk zarządzania transgranicznego (Mirwaldt, 2012).

Jak wskazywali Newman i Paasi (2013, s. 20), „tożsamość i granice wydają się być dwoma stronami tej samej monety”, bowiem „granice kreują tożsamość i są przez nią kreowane". Tożsamość transgraniczna będąca wypadkową tożsamości obszarów przygranicznych zdaje się stanowić przykład swoistej regionalnej tożsamości funkcjonalnej (Sadowski, 2005), zawiązanej z uświadomionych przez mieszkańców interesów regionu, z poczucia przynależności i funkcjonowania na określonym terytorium. Nie jest to tożsamość oparta na wspólnej kulturze, odwrotnie - powstaje z różnic między kulturami, potrzeby budowania pomostów między nimi. Wyrasta z pragmatycznego współdziałania, wymuszonego koniecznością współżycia na określonym terytorium i podejmowania działań przy udziale społeczności lokalnej (Kinal, 2007). Podstawą takiej tożsamości są więc elementy nierozerwalnie związane $\mathrm{z}$ istotą pogranicza: bliskość innego państwa, obecność granicy (w sensie realnym, prawnym, ale i symbolicznym), koegzystowanie odmiennych kulturowo społeczności, świadomość mniejszych lub większych relacji między nimi i najczęściej uczestnictwo w nich.

Tożsamościowy wymiar współpracy transgranicznej to innymi słowy tworzenie (transgranicznych) tożsamości przestrzennych, to proces, w którym tożsamość współpracy jest wytwarzana i odtwarzana zarówno od góry (poza regionem, egzogenicznie, przez podmioty krajowe i międzynarodowe), jak i od dołu (wewnątrz regionu, endogenicznie, poprzez odczucia mieszkańców dotyczące współpracy oraz narracje władzy lokalnej na ten temat) (Paasi, 2003; Terlouw, 2009; Zimmerbauer, 2011; Veemaa, 2012). W niniejszym opracowaniu przyjęto perspektywę, zgodnie z którą „reprezentacje przestrzenne tworzone przez aktorów regionalnych są zawsze częścią szerszego projektu budowania tożsamości (polityki tożsamości regionalnej), który idealnie nadaje się do odtwarzania tych reprezentacji poprzez świadomość ludzi” (Veemaa, 2012, s. 1650). Sposobem wskazania, na ile skutecznie współpraca transgraniczna rozwija się w wymiarze tożsamościowym, mogą być badania nad świadomością zbiorową, które pozwoliłyby ocenić, na ile współpraca ta stała się wśród mieszkańców terenów przygranicznych ważną perspektywą postrzegania sąsiedzkich relacji, 
wyrażającą się: 1) w deklarowanej potrzebie rozwoju współpracy transgranicznej; 2) w zwracaniu uwagi na efekty tej współpracy; 3) w sposobie postrzegania partnerstwa między krajami; 4) w świadomości badanych o tym, w jakich obszarach i poprzez jakiego typu kontakty współpraca ta rozwija się najlepiej, co stanowi zagrożenie, a co szansę na dalszy jej rozwój. Powyższe kwestie staną się tym samym podstawowymi elementami dociekań badawczych przedstawionych w niniejszym artykule. Rozpocząć należy je jednak od przybliżenia sytuacji na polsko-ukraińskiej granicy - w kontekście częstotliwości i celów przekraczania granicy przez obywateli obu państw - silnie oddziaływującej na życie codzienne mieszkańców terenów przygranicznych.

\section{SPECYFIKA POGRANICZA POLSKI I UKRAINY}

Przykładem dość niezwykłym dla obszarów przygranicznych Polski, ale też w skali całej Unii Europejskiej, jest pogranicze polsko-ukraińskie, w tym dwa sąsiadujące ze sobą regiony (Województwo Lubelskie oraz Obwód Wołyński), wchodzące w skład Euroregionu Bug. Obszar ten ma charakter peryferyjny, zarówno w kontekście Polski, jak i Ukrainy. Ponadto jedną z jego charakterystycznych cech jest duża dysproporcja pomiędzy stroną polską i ukraińską. Z danych określających poziom dysproporcji rozwojowych regionów (NUTS2) położonych na styku granicy Polski, mierzony wartością PKB per capita według parytetu siły nabywczej, wynika, że największą asymetrią ze wszystkich tych terenów charakteryzuje się pogranicze polsko-ukraińskie, najgorzej wypada zaś pod tym względem właśnie pogranicze lubelsko-wołyńskie (Jakubowski i in., 2017). Powoduje to określone konsekwencje gospodarcze, społeczne i polityczne. Są to zwłaszcza ekonomiczne migracje za pracą z Ukrainy do Polski, nasilony ruch graniczny, tworzący rozdrobnione powiązania handlowe gospodarki nieformalnej, handel przygraniczny typu bazarowego, wzmagający natężenie ruchu i zmniejszający przepustowość przejść. Sytuacja ta dodatkowo wpływa na umacnianie reżimu granicznego związanego z zewnętrzną granicą UE. Uwypukla też różnice w systemie prawno-instytucjonalnym, ale może także rodzić określone napięcia społeczne, $\mathrm{w}$ tym te bazujące na uproszczeniach, uprzedzeniach i stereotypach (Leszczak, 2019).

Sytuacja geopolityczna, różnice ekonomiczne, ale i duża ilość unijnych środków na inicjatywy transgraniczne spowodowały zdecydowany wzrost aktywności obu społeczności ponad granicami. Od kilkunastu lat systematycznie w ramach 
Euroregionu Bug wzrasta ruch graniczny, następuje wyraźny wzrost w ilości kontaktów gospodarczych oraz we wzajemnej wymianie handlowej (Osikowicz, 2017). Kumuluje on aktywność w wielu przestrzeniach współpracy na pograniczu Polski i Ukrainy. Coraz więcej regionów Ukrainy i województw Polski zawiera umowy o współpracy międzyregionalnej, a sam proces podpisywania dwustronnych umów o partnerstwie wykazuje trwałą tendencję wzrostową (Kovalisko, Mot, 2020). Jednocześnie jednak analiza projektów realizowanych w ramach programu współpracy transgranicznej Polska - Białoruś - Ukraina w latach 2007 - 2013 (Dołzbłasz, 2017) oraz perspektyw finansowych i pierwszych efektów programu z lat 2014-2020 pokazuje, że inicjatywy te faktycznie sprzyjają rozwijaniu relacji transgranicznych i pomagają przełamywać bariery mentalne, nie są one jednak w stanie przyczynić się realnie do przezwyciężenia peryferyjności gospodarczej i społecznej regionów położonych wzdłuż wschodniej granicy Polski (Jakubowski i in., 2017). Głównym czynnikiem kształtującym współpracę transgraniczną w ramach wspomnianego programu jest udział w projektach beneficjentów z największych miast pogranicza (Lublin, Rzeszów, Lwów, Łuck) i ich okolic. Oznacza to, że czynnik bliskości granicy nie odgrywa aż tak ważnej roli w inicjowaniu współpracy, a obecność przejść granicznych ma charakter drugorzędny (Dołzbłasz, 2017). Większa część środków wspierających współpracę transgraniczną trafia więc do oddalonych od granicy dużych ośrodków miejskich, a nie bezpośrednio do obszarów przygranicznych znajdujących się w promieniu $50 \mathrm{~km}$ od granicy.

Wsparcie dla regionów transgranicznych jest obecnie w państwach Europy jednym z ważniejszych wyzwań całej europejskiej polityki rozwoju, której założeniem jest przełamywanie barier i zmniejszenie stopnia peryferyjności obszarów przygranicznych m.in. poprzez łagodzenie negatywnych skutków istnienia granicy (Programming dokument, 2014). Jednakże przyznawane środki na działania transgraniczne stanowią jedynie skąpą część Europejskiej Polityki Spójności i Europejskiego Instrumentu Sąsiedztwa (ENI/ENPI), co w przypadku pogranicza polsko-ukraińskiego oznacza, że zmniejszenie luki rozwojowej wynikającej z ich peryferyjnego położenia zależy głównie od skutecznej realizacji polityk regionalnych na poziomie krajowym i regionalnym (Jakubowski i in., 2016).

Uwarunkowania prawne i obostrzenia związane z przekraczaniem wschodniej granicy UE powodują, że dostępność przejść i sam ruch graniczny to podstawowe punkty odniesienia $\mathrm{w}$ analizie współpracy transgranicznej. $Z$ tej perspektywy przejście graniczne nie jest jedynie punktem przekraczania granicy - to miejsce zintensyfikowanej komunikacji między stronami, gdzie przecinają się relacje 
społeczne i gospodarcze, gdzie tworzy się węzeł tranzytowych i turystycznych przepływów. Przejścia są cennym zasobem dla graniczących ze sobą terenów i lokalnej społeczności, a jest tak zwłaszcza wtedy, gdy tworzą one przestrzeń mobilności pomiędzy państwami różniącymi się na płaszczyźnie ekonomicznej. Wytwarzają bowiem wtedy dodatkową aktywność ludności, co musi rodzić także swoje konsekwencje społeczne i kulturowe (Matejko, 2008; Sohn, 2014).

Z badań ruchu granicznego nadzorowanych przez Urząd Statystyczny w Rzeszowie (Ruch graniczny, 2019) wynika, że główny cel podróży mieszkańców Ukrainy do Polski to zakupy (w okolicach 80\%). Są one jednak częścią całego systemu handlu przygranicznego, czyli dokonywania zakupów przez osoby fizyczne w państwie sąsiedzkim i przewożenia ich przez granicę - w określonych przepisami limitach - bez potrzeby odprawy celnej, dla własnych celów konsumpcyjnych, ale i na potrzeby małego handlu, w tym aktywności w gospodarce nieformalnej. $Z$ danych zbieranych przez urząd wynika, że ponad $70 \%$ cudzoziemców (w zdecydowanej większości Ukraińców - ok. 97\%) przekracza granicę polsko-ukraińską co najmniej kilka razy w tygodniu, $66 \%$ to zaś osoby mieszkające w odległości do $50 \mathrm{~km}$ od granicy $(51 \%$ do $30 \mathrm{~km})$. W ciągu 10 lat (2009-2019) liczba przekroczeń granicy polsko-ukraińskiej przez obywateli Ukrainy wzrosła czterokrotnie (Rosik i in., 2020: 42); tendencja ta w dużej mierze jest efektem wprowadzenia w 2009 r. małego ruchu granicznego między obydwoma krajami. Nie wiadomo jeszcze dokładnie, jak na ten trend wpłynie sytuacja z pandemią Covid-19, kiedy to przekraczanie granicy polsko-ukraińskiej stało się jeszcze trudniejsze, dłuższe i obłożone dodatkowymi obostrzeniami. Tę kwestię przyjdzie rozstrzygnąć, gdy sytuacja epidemiczna się ustabilizuje (albo na tyle rozciągnie się w czasie, że zostanie przyjęta jako trwały, a nie tymczasowy, który niedługo się skończy, element rzeczywistości).

Charakterystyka osób przekraczających polsko-ukraińską granicę, wynikająca $z$ danych statystycznych, odpowiada wynikom badań własnych realizowanych wśród mieszkańców obszarów przygranicznych Polski i Ukrainy, zamieszkałych w ramach Euroregionu Bug w okolicach $50 \mathrm{~km}$ od przejścia granicznego Dorohusk-Jagodin. Prezentowane w tekście zestawienia statystyczne opierają się na badaniach przeprowadzonych w dniach 16-20 grudnia 2019 roku na wspomnianym przejściu granicznym i okolicach, po obu stronach granicy. Ankiety zebrano od 305 osób: były to osoby przekraczające granicę polsko-ukraińską i ukraińsko-polską (151 Polaków i 154 Ukraińców), które zadeklarowały, że przekraczają tę granicę przynajmniej raz w roku i są mieszkańcami terenów przygranicznych. Dobór próby miał charakter celowo- 
-losowy, polegający na celowym wyborze przejścia granicznego, dni i godzin badania oraz losowym wskazaniu respondenta - tak, aby próba odzwierciedlała zróżnicowanie osób przekraczających granicę pod względem narodowości, płci i wieku. Struktura próby przekraczających granicę pod względem tych cech społeczno-demograficznych prezentuje się podobnie w podgrupach badanych po obu stronach granicy. Zauważalna jest nieznaczna przewaga mężczyzn (ok. $58 \%$ do $42 \%$ ), ze średnią wieku w okolicach 41-42 lat, w obu podgrupach bliską medianie.

W ramach wspomnianych badań systematyczne przekraczanie granicy - co najmniej raz w miesiącu - deklarują przede wszystkim ukraińscy badani (80\% $\mathrm{z}$ nich, gdzie $37 \%$ to osoby przekraczające granicę kilka razy w tygodniu lub codziennie), po stronie polskiej $27 \%$ respondentów wyjeżdża na Ukrainę raz w miesiącu lub częściej, a ponad połowa deklaruje, że robi to jedynie raz w roku. Konfrontując te dane wraz z celowością wyjazdów za polską/ukraińską granicę (Ryc. 1), warto odnotować, że ponad 66\% badanych Ukraińców deklaruje, że wyjazd do Polski ma głównie charakter ekonomiczny lub zawodowy, a więc, że jest to wyjazd w prywatnych celach zarobkowych $(38,0 \%)$, wyjazd w celach służbowych $(18,7 \%)$ lub na zakupy (9,4\% w ramach odp. „inny”). Wśród polskich respondentów odsetek ten - motywacji ekonomicznych lub zawodowych - jest znacznie mniejszy, w okolicach 37\% (najwięcej, 38,6\% Polaków wskazało cel

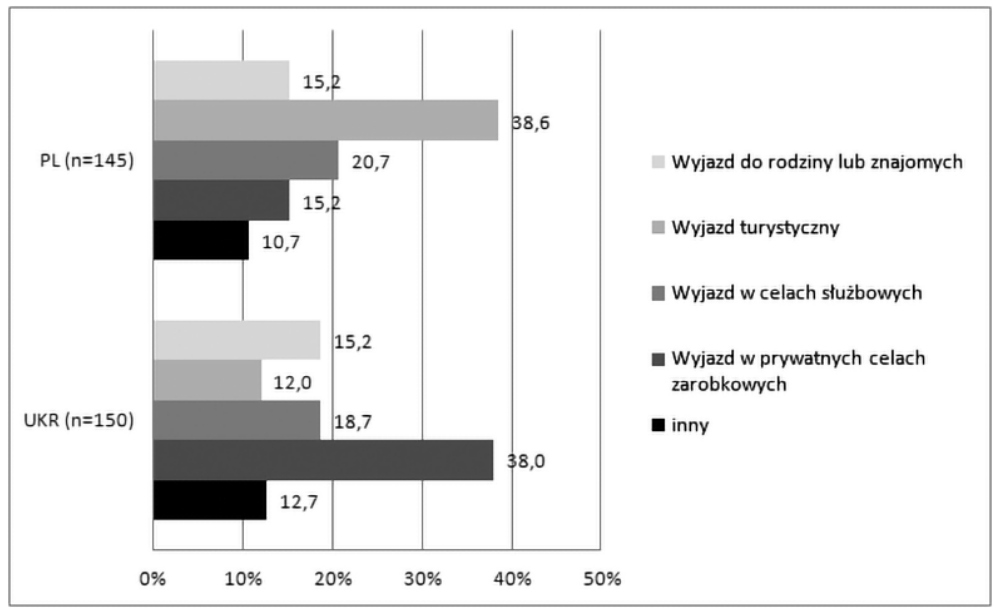

Ryc. 1. Deklarowany najczęstszy cel przekraczania granicy Polski i Ukrainy.

Źródło: badania własne. 
turystyczny jako najczęstszy powód podróży na Ukrainę, a była to odpowiedź, którą najrzadziej z kolei wskazywali badani obywatele Ukrainy - 11,7\% z nich). Oznacza to, że badani Ukraińcy najczęściej przekraczają granicę w celach ekonomicznych i zawodowych, Polacy zaś częściej robią to z powodów nieekonomicznych i niezawodowych (suma wskazań na cel turystyczny oraz społeczny jako wyjazd do rodziny i znajomych - 53,8\% polskich respondentów przekraczających granicę).

Odnotowywane przypadki przekraczania granicy polsko-ukraińskiej z roku na rok wzrastają, jednakowoż przejścia graniczne wciąż stanowią dużą barierę dla tej mobilności. Na pytanie o główne problemy występujące na granicy Polski i Ukrainy odpowiedź „zbyt długi czas oczekiwania na przekroczenie granicy” była zdecydowanie najczęściej wskazywaną odpowiedzią i to na poziomie $85 \%$ (Ukraińcy) i 90\% (Polacy) próby, podczas gdy żadna z sześciu pozostałych odpowiedzi nie zyskała poparcia większego niż 23\% (ankieta przewidywała możliwość zaznaczenia dwóch odpowiedzi). Znaczenie dla szacowanego czasu przekraczania granicy - na co wskazuje też istotny statystycznie związek między zmiennymi - ma cel podróży $\left(\mathrm{Z} \chi^{2}=35,35 ; \mathrm{df}=12 ; \mathrm{p}<0,001\right)$ oraz częstotliwość przekraczania granicy $\left(\chi^{2}=35,35 ; \mathrm{df}=15 ; \mathrm{p}<0,001\right)$. Najdłuższe szacunki czasowe deklarują osoby przekraczające granice „w prywatnych celach zarobkowych” (połowa $\mathrm{z}$ nich uważa, że czas przekraczania granicy - w obie strony - przekracza cztery godziny, $28 \%$, że mieści się w czasie do dwóch godzin). Inaczej przejście do sąsiedniego państwa widzą osoby deklarujące cel turystyczny - $17 \%$ twierdzi, że przeciętnie zajmuje to ponad cztery godziny, większość jest zaś zdania, że zajmuje to co najwyżej dwie godziny (twierdzi tak 65\% przekraczających o kierunku z Polski do Ukrainy i 54\% z nich o kierunku odwrotnym).

\section{WSPÓŁPRACA TRANSGRANICZNA Z PERSPEKTYWY MIESZKAŃCÓW - WYNIKI BADAŃ}

Pytając o to, jak powinna wyglądać współpraca transgraniczna (co jej sprzyja, a co przeszkadza, kto powinien ją prowadzić i jakie działania mogłyby jej pomóc) pytamy głównie o wyobrażenie tej współpracy. $\mathrm{O}$ to, jak w świadomości badanych rysuje się pewien jej wzór. Ten z kolei zależeć będzie od tego, co konstruuje także społeczną tożsamość - od posiadanej wiedzy, przyjętych schematów rozumienia świata, a w jakiejś mierze także od interesów (grupowych i indywidualnych). Wyobrażenie o rzeczywistości, jej oceny, postawy w stosunku 
do niej, które są mniej lub bardziej wspólne ludziom z określonego środowiska, tworzą świadomość zbiorową (Sztompka, 2012; Ziółkowski, 1989), a jej badanie umożliwia zorientowanie się, m.in., jak procesy makrospołeczne (np. współpraca transgraniczna) postrzegane są z perspektywy mikro.

Coraz większa skala kontaktów ponad granicami między polskimi a ukraińskimi podmiotami znajduje także swoje odzwierciedlenie w świadomości społecznej mieszkańców obszarów przygranicznych i postrzeganiu przez nich powstałych transgranicznych relacji. Wśród badanych dominuje perspektywa postrzegania tych kontaktów jako opartych głównie na relacjach ekonomicznych - zdecydowana większość ankietowanych wskazuje, że w relacjach między mieszkańcami Polski i Ukrainy dominują kontakty handlowe, takie jak zakupy, handel, korzystanie z usług itp. Należy jednak zauważyć, że Polacy w nieco większym stopniu wskazują, że podstawą tych relacji są kontakty handlowe $(81,9 \%)$ i gospodarcze (28,2\%) - u Ukraińców to odpowiednio 74,7\% i 25,3\% (Ryc. 2). Zasadnicza różnica między obiema grupami narodowościowymi widoczna jest jednak w hierarchii wskazań kolejnych kategorii relacji. Dla znacznej części ukraińskich ankietowanych kontakty społeczne i towarzyskie są także ważnymi elementem sąsiedzkich relacji (43\% wskazań), na turystykę zwróciło uwagę jedynie 16,7\% ukraińskich ankietowanych (wśród Polaków, to odpowiednio 30,2\% k. społeczne i towarzyskie, $27,5 \%$ k. turystyczne). Różnica w ocenie znaczenia turystyki widoczna była już przy celach wyjazdowych przy przekraczaniu granicy, większe znaczenie kontaktów towarzyskich dla ukraińskiej części próby może

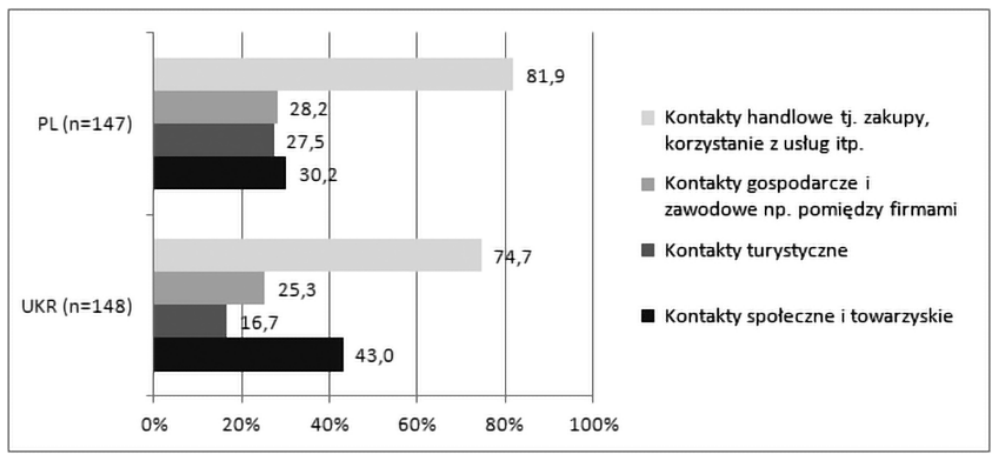

Ryc. 2. Dominujące kontakty w relacjach pomiędzy mieszkańcami Polski i Ukrainy w opinii respondentów (możliwość wskazania max. 2 odp.).

Źródło: badania własne. 
wynikać także z sytuacji migracyjnej, z dominującego kierunku tych mobilności (z Ukrainy do Polski).

Respondenci w dość zdecydowany sposób zadeklarowali, że współpraca transgraniczna pomiędzy Polską a Ukrainą, $\mathrm{w}$ tym pomiędzy regionami leżącymi przy granicy obu państw, jest potrzebna - wyraźnie ponad $90 \%$ pozytywnych („Zdecydowanie tak” oraz „Raczej tak”) wskazań w próbie (Tab.1). Większość na poziomie bliskim $70 \%$ dostrzega także efekty współpracy transgranicznej, nieco więcej (ok. 75\%) uznaje relację w obszarze polityki i gospodarki między Polską a Ukrainą jako strategiczne partnerstwo. Na poziomie wszystkich respondentów zauważalna jest więc duża zgodność co do potrzeby zacieśniania współpracy między krajami i umiarkowanego zadowolenia z tego, że dotychczasowe próby budowania współpracy transgranicznej odcisnęły już na rzeczywistości swoje piętno. Zauważalne są jednak różnice $\mathrm{w}$ rozkładach odpowiedzi wśród mieszkańców obszarów przygranicznych w zależności od tego, którą stronę granicy zamieszkują. $Z$ wyjątkiem pytania o efekty współpracy transgranicznej, dla pozostałych zmiennych można wskazać istotny statystycznie związek $(\mathrm{p}<0,001)$ ze zmienną wskazującą na państwo pochodzenia. Ukraińscy respondenci znacznie częściej niż polscy, niezależnie od pytania, przyjmowali zdecydowane stanowisko

Tab. 1. Ocena znaczenia i efektów współpracy transgranicznej między Polską a Ukrainą według ankietowanych mieszkańców terenów przygranicznych

\begin{tabular}{|c|c|c|c|c|}
\hline & \multicolumn{2}{|c|}{$\begin{array}{c}\text { Państwo } \\
\text { pochodzenia }\end{array}$} & \multirow{2}{*}{$\begin{array}{c}\text { Ogółem } \\
\%\end{array}$} \\
\hline & & PL \% & UKR \% & \\
\hline \multirow{4}{*}{$\begin{array}{c}\text { A. Czy współpraca transgraniczna } \\
\text { pomiędzy Polską a Ukrainą jest } \\
\text { potrzebna? } \\
\text { PL }(n=151) ; \text { UKR }(n=153)\end{array}$} & Zdecydowanie tak & 47,5 & 75,1 & 61,3 \\
\hline & Raczej tak & 44,1 & 22,9 & 33,5 \\
\hline & Raczej nie & 7,4 & 1,0 & 4,2 \\
\hline & Zdecydowanie nie & 1,0 & 1,0 & 1,0 \\
\hline \multirow{4}{*}{$\begin{array}{l}\text { B. Czy współpraca transgraniczna } \\
\text { pomiędzy regionami leżącymi przy } \\
\text { granicy Polski i Ukrainy jest potrzebna? } \\
\text { PL }(n=151) ; \text { UKR }(n=153)\end{array}$} & Zdecydowanie tak & 44,6 & 71,1 & 57,8 \\
\hline & Raczej tak & 48,5 & 24,9 & 36,7 \\
\hline & Raczej nie & 5,9 & 2,5 & 4,2 \\
\hline & Zdecydowanie nie & 1,0 & 1,5 & 1,2 \\
\hline \multirow{4}{*}{$\begin{array}{c}\text { C. Czy efekty współpracy transgranicz- } \\
\text { nej są odczuwalne? } \\
\text { PL }(n=147) ; \text { UKR }(n=148)\end{array}$} & Zdecydowanie tak & 14,1 & 22,3 & 18,2 \\
\hline & Raczej tak & 54,0 & 47,2 & 50,6 \\
\hline & Raczej nie & 26,8 & 26,9 & 26,9 \\
\hline & Zdecydowanie nie & 5,1 & 3,6 & 4,3 \\
\hline
\end{tabular}




\begin{tabular}{|c|c|c|c|c|}
\hline \multicolumn{2}{|c|}{} & \multicolumn{2}{|c|}{$\begin{array}{c}\text { Państwo } \\
\text { pochodzenia }\end{array}$} & \multirow{2}{*}{$\begin{array}{c}\text { Ogółem } \\
\%\end{array}$} \\
\cline { 3 - 4 } \multicolumn{2}{|c|}{} & PL $\%$ & UKR $\%$ & \\
\hline \multirow{2}{*}{$\begin{array}{c}\text { D. Czy Polska i Ukraina są partnerami } \\
\text { strategicznymi w obszarze polityki } \\
\text { i gospodarki? }\end{array}$} & Zdecydowanie tak & 13,7 & 51,0 & 32,6 \\
\cline { 2 - 4 } \begin{tabular}{c} 
PL (n=140); UKR (n=152) \\
\cline { 2 - 4 }
\end{tabular} & Raczej tak & 50,0 & 37,6 & 43,8 \\
\cline { 2 - 5 } & Raczej nie & 35,8 & 6,7 & 21,1 \\
\hline
\end{tabular}

pozytywne (odp. „zdecydowanie tak”, Tab. 1., w pyt. A o 28\% częściej, B - 27\%, C- $8 \%, D-37 \%)$. Na pytanie o strategiczne partnerstwo Polski i Ukrainy jedynie $11 \%$ z części ukraińskiej próby zaprzecza takiej relacji, przy 36\% ankietowanych z Polski.

Respondenci zostali też poproszeni o wskazanie czynników, które wpływają na kształtowanie się współpracy transgranicznej między Polską a Ukrainą, ich odpowiedzi tworzą dość spójny obraz czynników sprzyjających rozwojowi współpracy transgranicznej oraz tych, które mogą ten rozwój utrudnić (Tab. 2.). Chociaż odpowiedzi były do siebie zbliżone, to bardziej szczegółowe zwrócenie uwagi na powstające różnice może dostarczyć ciekawej i zniuansowanej wiedzy o sposobach myślenia respondentów (Tab. 2.). Podobieństwo języka było najczęstszą (u Ukraińców) lub jedną z dwóch najczęściej (u Polaków) wskazywanych odpowiedzi. Ci drudzy częściej deklarowali, że rozwojowi współpracy sprzyjają wspólne interesy gospodarcze (PL: 46,6\%, UKR: 25,5\%), dla obywateli Ukrainy ważniejsza jest jednak wzajemna sympatia Polaków i Ukraińców (PL: 19,9\%, UKR:31,7\%). Na podobieństwo kultury obie nacje zwróciły uwagę w podobnej skali - tę odpowiedź wskazała 1/5 respondentów. Ukraińscy badani zwracali więc uwagę na walory ułatwiające komunikację, zaś niemal co drugi polski respondent wskazywał głównie interes gospodarczy.

Głównym czynnikiem utrudniającym rozwój współpracy jest - najczęściej wskazywana zarówno przez Polaków, jak i Ukraińców - przeszłość historyczna, która do dzisiaj tworzy napięcia i wzajemne pretensje. Odpowiedź tę zaznaczyła niemal połowa $(45,6 \%)$ respondentów po polskiej stronie oraz $1 / 3(34 \%)$ próby ukraińskiej. Stosunkowo często respondenci z Polski zaznaczali też bariery prawne $(35,4 \%)$ i administracyjne $(29,9 \%)$ Co czwarty przekraczający granicę po ukraińskiej stronie zaznaczał natomiast „niewystarczające fundusze unijne i własne na rozwój", nieco rzadziej także bariery administracyjne (23,3\%). Przy analizie wyników zwraca też uwagę bardzo niski odsetek odpowiedzi związanych 
Tab. 2. Czynniki wpływające na kształtowanie się polsko-ukraińskiej współpracy transgranicznej w opinii respondentów: sprzyjające vs utrudniające*

\begin{tabular}{|c|c|c|}
\hline CZYNNIKI SPRZYJAJACCE & PL $(n=146) \%$ & UKR $(n=147) \%$ \\
\hline Dostępność funduszy unijnych na ten cel & 5,5 & 3,4 \\
\hline Dostępność środków unijnych & 4,1 & 6,9 \\
\hline Podobieństwo języka & 32,9 & 36,6 \\
\hline Podobieństwo kultury & 21,2 & 20,0 \\
\hline Podobieństwo stylu życia & 13,0 & 10,3 \\
\hline $\begin{array}{c}\text { Sprzyjająca polityka samorządowa wspierająca polsko-ukraiń- } \\
\text { ską współpracę transgraniczną }\end{array}$ & 17,1 & 9,7 \\
\hline Wspólne interesy gospodarcze & 46,6 & 25,5 \\
\hline Wspólne interesy polityczne & 9,6 & 12,4 \\
\hline Wzajemna sympatia Polaków i Ukraińców & 19,9 & 31,7 \\
\hline inne & 0,7 & 3,4 \\
\hline CZYNNIKI UTRUDNIAJĄCE & PL $(n=145) \%$ & UKR $(n=150) \%$ \\
\hline Bariery administracyjne & 29,9 & 23,3 \\
\hline Bariery językowe & 11,6 & 10,0 \\
\hline Bariery kulturowe & 4,1 & 10,0 \\
\hline Bariery prawne & 35,4 & 14,7 \\
\hline Brak zainteresowania taką współpracą po obu stronach granicy & 13,6 & 19,3 \\
\hline Brak zrozumienia dla możliwych efektów tej współpracy & 18,4 & 17,3 \\
\hline $\begin{array}{l}\text { Niewystarczające fundusze unijne i własne na rozwój } \\
\text { współpracy }\end{array}$ & 18,4 & 26,0 \\
\hline Przeszłość historyczna & 45,6 & 34,0 \\
\hline Różniące się interesy miast lub regionów & 2,7 & 5,3 \\
\hline inne & 0,7 & 0,7 \\
\hline
\end{tabular}

* Możliwość wyboru max. 2 odp. - wyniki nie sumują się do 100\%. W tabeli szarym kolorem zaznaczono wyniki $>20 \%$ wskazań.

Źródło: badania własne.

z barierami kulturowymi, językowymi czy różniącymi się interesami miast lub regionów.

Posiadając więc świadomość istnienia określonych barier, respondenci udzielali też odpowiedzi na pytanie o to, jakie formy ułatwień spowodowałyby wzrost efektywności współpracy transgranicznej. Zasadniczo udało się wyróżnić trzy takie odpowiedzi, na które najczęściej zgodnie w podobnej skali wskazywano 


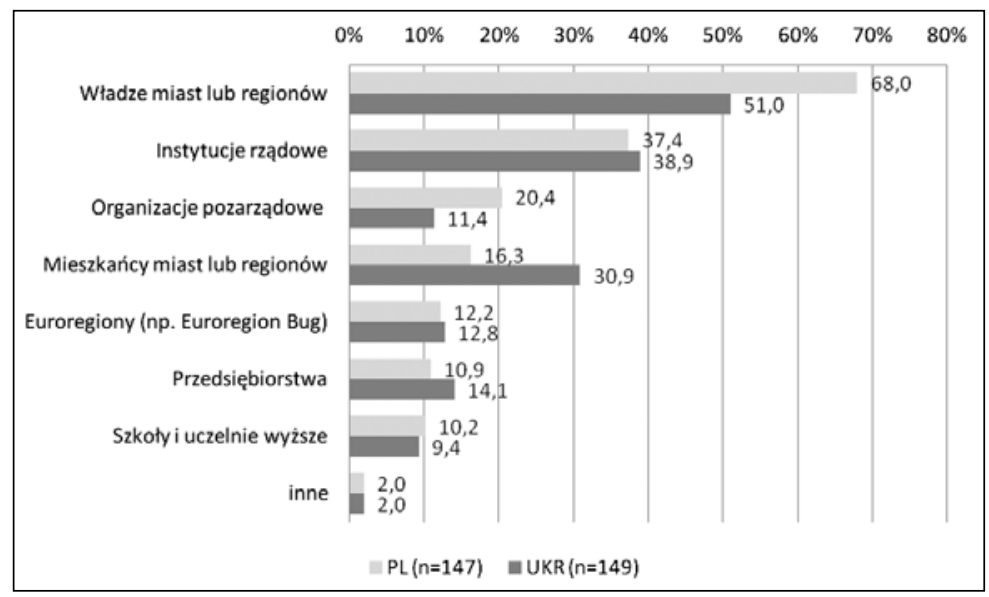

Ryc. 3. Podmioty, które powinny rozwijać polsko-ukraińską współpracę transgraniczną (możliwość wskazania max. 2 odp.).

Źródło: badania własne.

po obu stronach granicy. Po pierwsze, najczęściej wskazywano na uproszczenie przepisów związanych z przekraczaniem granicy przez mieszkańców terenów przygranicznych (zaznaczyło tak 61,5\% badanych Polaków i 55,6\% Ukraińców). Po drugie, ważne - zdaniem respondentów - byłoby także zwiększenie liczby przejść granicznych, na co zawracała uwagę mniej więcej $1 / 3$ badanych (30\% Polaków i 35\% Ukraińców). I po trzecie, poprawa istniejącej infrastruktury granicznej, co było wskazywane przez co trzeciego respondenta z Polski i Ukrainy.

Zdaniem ankietowanych współpracę transgraniczną powinny rozwijać przede wszystkim władze miast lub regionów. Była to odpowiedź, którą po polskiej stronie wskazało $68 \%$ respondentów, a po ukraińskiej $51 \% \mathrm{z}$ nich. Oczekiwania zostały też skierowane do instytucji rządowych, zajmując drugie miejsce wśród najpopularniejszych odpowiedzi (polscy badani - 37,4\%, ukraińscy - 38,9\%). To, którą z alternatyw należy wymienić jako trzecią (wśród najczęściej wskazywanych odpowiedzi), zależy już od narodowości - 20\% przekraczających granicę Polaków uważa, że współpracę między państwami powinny rozwijać także organizacje pozarządowe, $31 \%$ Ukraińców wskazuje zaś bezpośrednio - być może ze względu na słabo jeszcze rozwinięty tzw. trzeci sektor - na mieszkańców miast lub regionów. 


\section{WNIOSKI}

Badania wykazały, że w świadomości mieszkańców terenów przygranicznych dominuje perspektywa postrzegania transgranicznych relacji polsko-ukraińskich jako opartych w dużej mierze na kontaktach ekonomicznych. W świadomości zbiorowej znajdujemy więc odzwierciedlenie rzeczywistości i potwierdzenie analiz, które odnotowywały w regionach przygranicznych Polski i Ukrainy intensyfikację przemieszczeń ludności i wysoką dynamikę procesów gospodarczych (Cierpiał-Wolan, 2017; Jakubowski i in., 2017; Osikowicz, 2017), nasilonych od 2014 r. w wyniku niestabilnej sytuacji politycznej na Ukrainie. Natężenie polsko-ukraińskich interakcji transgranicznych - rejestrowanych, nierejestrowanych, będących w szarej strefie - jest efektem przede wszystkim wyraźnych dysproporcji regionalnych. Dominacja deklarowanych relacji o charakterze handlowym, w kontekście wyraźnych różnic ekonomicznych obu krajów, handlu małej skali, wskazuje na pewną niedojrzałość tożsamości transgranicznej, która do odpowiedniego rozwoju potrzebuje stałych, możliwie długookresowych reguł wzajemnych kontaktów ekonomicznych i społecznych (Sadowski, 2007), aby asymetrie potencjałów między regionami i doraźne kontakty handlowe zmienić w stabilny system wzajemnych powiązań gospodarczych, politycznych i społecznych.

Świadomość tych asymetrii regionalnych obecna jest w postrzeganiu współpracy transgranicznej przez mieszkańców terenów przygranicznych po obu stronach granicy. Różnicę między ich perspektywami są wyraźnie zauważalne. Polacy widzą relacje z sąsiadem przede wszystkim przez pryzmat relacji gospodarczych i handlowych, choć zauważają bliskość kulturową, postrzegając też Ukrainę jako atrakcyjny cel turystycznych wyjazdów. Ukraińcy w zachodnim partnerze także widzą głównie kontrahenta do umów handlowych, tranzytowych czy gospodarczych, dając jednak do zrozumienia, że Polska jawi się także jako dobre miejsce dla edukacji oraz partner w budowaniu relacji społecznych i towarzyskich, jako państwo kulturowo bliskie i przyjazne obywatelom Ukrainy. Jednocześnie po obu stronach panuje przekonanie, że współpraca nie tylko jest niezbędna - zarówno na poziomie rządowym, jak i lokalnie, między przygranicznymi regionami i poszczególnymi miejscowościami - ale już dotychczasowe relacje polsko-ukraińskie przyniosły swoje owoce (takie przekonanie wyrażało 2/3 badanych zarówno po polskiej, jak i ukraińskiej stronie). Głównymi barierami dla rozwoju współpracy transgranicznej między sąsiadami - tuż obok barier ekonomiczno-prawnych i różnie ocenianej infrastruktury granicznej - są także 
bariery społeczne, jak szczególnie negatywne doświadczenia historyczne czy różnice w mentalności.

Mimo dominacji kontaktów handlowych istnieje duża świadomość wśród badanych, jak wiele elementów kulturowych łączą oba narody, zwracano też uwagę na walory ułatwiające komunikację między narodami. W odniesieniu do wyników badań można wskazać, że budowanie silniejszej tożsamości transgranicznej na pograniczu polsko-ukraińskim ma dużą szansę powodzenia dzięki czterem elementom: Po pierwsze, współpracy ponad granicami sprzyja podobieństwo języka, które umożliwia szybszą orientację w obcym środowisku językowym, zmniejsza ryzyko błędów w komunikacji. Po drugie, wspólne interesy gospodarcze, które tworzą sieć wzajemnych celów i potrzeb, budując poczucie, że obu stronom to się po prostu opłaca. Po trzecie, wzajemna sympatia, która potrafi budować i umacniać więzi, sprzyja dialogowi i potrzebie poznania tej drugiej strony. I w końcu, po czwarte, podobieństwo kultur jako czynnik ułatwiający budowanie relacji sąsiedzkich poprzez spotkanie i poznanie tej drugiej strony, tworząc możliwie szybko płaszczyznę porozumienia. Powyższe elementy to jednocześnie cztery najczęściej wskazywane przez respondentów odpowiedzi na pytanie o czynniki sprzyjające współpracy pomiędzy Polakami i Ukraińcami, co raczej dobrze rokuje na jej przyszłość.

\section{BiBLIOGRAFIA:}

Boman, J., Berg, E. (2007). Identity and Institutions Shaping Cross-border Co-operation at the Margins of the European Union. Regional and Federal Studies, 17(2), 195-215. DOI: $10.1080 / 13597560701318516$.

Böhm, H., Opioła, W., Drosik, A. (2019). Cross-border Social Capital. An Analysis of Selected Elements as Exemplified by the Praded Euroregion. W: J. Jańczak (red.). Old Borders-New Challenges, New Borders-Old Challenges: De-Bordering and Re-Bordering in Contemporary Europe (ss. 99-114). Berlin: Logos Verlag.

Buller, L., Kotarski, H., Pachkovskyy, Y. (red.). (2017). Contemporary Socio-Economic Issues of Polish-Ukrainian Cross-border Cooperation. Warszawa: PL-BY-UA 20142020 Center of European Projects.

Cierpiał-Wolan, M. (2017). Wpływ dynamicznych przemieszczeń ludności na rozwój społeczno-gospodarczy polsko-ukraińskich obszarów transgranicznych. W: A. Miszczuk (red.). Wyzwania rozwojowe pogranicza polsko-ukraińskiego (ss. 121-145). Lublin: Norbertinum.

Jakubowski, A., Bronisz, U., Miszczuk, A. (2017). Polityka spójności oraz europejski instrument sąsiedztwa i partnerstwa jako narzędzia wsparcia współpracy transgranicznej na wewnętrznych i zewnętrznych granicach Unii Europejskiej. Roczniki Nauk Społecznych, 45(3), 73-89. DOI: 10.18290/rns.2017.45.3-5. 
Jakubowski, A., Miszczuk, A., Kawałko, B., Komornicki, T., Szul, R. (2016). The EU's New Borderland: Cross-border relations and regional development. London: Taylor \& Francis.

Kinal, A. (2007). Wielokulturowość pogranicza - kapitał czy obciążenie? W: M. Zielińska, B. Trzop, K. Lisowski (red.). Transgraniczność w perspektywie socjologicznej: pogranicza Polski w integrującej się Europie (ss. 175-184). Zielona Góra: Lubuskie Towarzystwo Naukowe.

Komornicki, T., Wiśniewski, R. (2017). Border traffic as a measure of trans-border relations. Mitteilungen der Österreichischen Geographischen Gesellschaft, 159, 151-172. DOI: $10.23781 / \operatorname{moegg} 159-151$.

Kovalisko, N., Mot, K. (2017). The specificity of cross-border mobility in the context of Ukrainian-Polish cooperation. W: L. Buller, Contemporary Socio-Economic Issues of Polish-Ukrainian Cross-border Cooperation (s. 177-200). Warszawa: Center of European Projects.

Leszczak, O. (2019). Polska i Polacy we współczesnym ukraińskim etnicznym obrazie świata. Część I: Ogląd struktury kulturowo-cywilizacyjnej. Przegląd Wschodnioeuropejski, 10(1), 229-240. DOI: 10.31648/pw.4516.

Levy, O., Peiperl, M., Bouquet, C. (2013). Transnational social capital: A conceptualization and research instrument. International Journal of Cross Cultural Management, 13(3), 319-338. DOI: 10.1177/1470595813485940.

Matejko, E. (2008). Przejście graniczne jako zasób społeczności lokalnej. Pogranicze. Studia Społeczne, 14, 61-77.

Mirwaldt, K. (2012). The small projects fund and social capital formation in the PolishGerman border region: An initial appraisal. Regional Studies, 46(2), 259-272. DOI: 10.1080/00343404.2010.490210.

Miszczuk, A. (red.). (2017). Wyzwania rozwojowe pogranicza polsko-ukraińskiego. Lublin: Norbertinum.

Miszczuk, A. (2013). Uwarunkowania peryferyjności regionu przygranicznego. Lublin: Norbertinum.

Newman, D., Paasi, A. (2013). Odgradzanie i sąsiedztwo w postmodernistycznym świecie. Narracje granic w geografii politycznej. Pogranicze. Polish Borderlands Studies, 1(1), 12-34.

Osikowicz Ż. (2017). Współpraca transgraniczna Ukrainy i Polski w strukturze stosunków międzynarodowych na przykładzie wybranych euroregionów (zarys i problematyka), Zarzadzanie w Kulturze, 18(2), 237-249. DOI: 10.4467/20843976 ZK.17.014.7106.

Otok, S. (2006). Geografia polityczna. Warszawa: Wydawnictwo Naukowe PWN.

Paasi, A. (2001). Europe as a social process and discourse: considerations of place, boundaries and identity. European Urban and Regional Studies, 8(1), 7-28.

Paasi, A. (2003). Region and place: Regional identity in question. Progress in Human Geography, 27(4), 475-485. DOI: 10.1191/0309132503ph439pr.

Paasi A. (2009). The Resurgence of the 'Region' and 'Regional Identity': Theoretical 
Perspectives and Empirical Observations on Regional Dynamics in Europe, Review of International Studies, 35(S1), 121-146. DOI: 10.1017/S0260210509008456.

Programming document for eu support to eni cross-border cooperation (2014-2020) (2014). Pobrane z: https://ec.europa.eu/neighbourhood-enlargement/neighbourhood/cross-border-cooperation_en.

Ruch graniczny oraz wydatki cudzoziemców w Polsce i Polaków za granica w 2018 r. (2019). Warszawa/Rzeszów: Główny Urząd Statystyczny.

Ramutsindela, M. (2013). Experienced Regions and Borders: The Challenge for Transactional Approaches, Regional Studies, 47(1), 43-54. DOI: 10.1080/003434 04.2011.618121.

Rosik, P., Goliszek, S., Duma, P., Komornicki, T. (2020). Dostępność potencjałowa regionów w Europie-zasięg przestrzenny, długość podróży i efekt granicy (EUROAD-ACC) = Potential accessibility of European regions: spatial reach, travel duration and the border effect (EU-ROAD-ACC), Warszawa: IGiPZ PAN. DOI: $10.7163 / 9788361590071$.

Rybicka, E. (2016). Transgraniczność w kulturze a tożsamości regionalne. W:

D. Zawadzka, M. Mikołajczak, K. Sawicka-Mierzyńska (red.). Region a tożsamości transgraniczne. Literatura. Miejsca. Translokacje (ss. 24-36). Kraków: Universitas.

Rykiel, Z. (2005). Podstawy geografii politycznej. Warszawa: Polskie Wydawnictwo Ekonomiczne.

Sadowski, A. (2005). Od polski lokalnej do regionalnej. W: W. Wesołowski, J. Włodarz (red.). Kręgi integracji i rodzaje tożsamości (ss. 141-162). Warszawa: Scholar.

Sadowski, A. (2007). Przemiany transgranicza polsko-białoruskiego w warunkach Unii Europejskiej. W: M. Zielińska, B. Trzop, K. Lisowski (red.). Transgraniczność w perspektywie socjologicznej. Pogranicza Polski w jednoczącej się Europie (ss. 105-124). Zielona Góra: Lubuskie Towarzystwo Naukowe.

Sohn, C. (2014). Modelling Cross-Border Integration: The Role of Borders as a Resource, Geopolitics, 19(3), 587-608. DOI: 10.1080/14650045.2014.913029.

Sousa, L. D. (2013). Understanding European cross-border cooperation: A framework for analysis. Journal of European Integration, 35(6), 669-687. DOI: 10.1080/07036337.2012.711827.

Sparke, M. (2006). Political Geography: Political Geographies of Globalization (2) - Governance. Progress in Human Geography, 30(2), 1-16. DOI: 10.1191/030 $9132506 \mathrm{ph} 606 \mathrm{pr}$.

Svensson, S. (2015). The Bordered World of Cross-border Cooperation: The Determinants of Local Government Contact Networks within Euroregions, Regional \& Federal Studies, 25(3), 277-295. DOI: 10.1080/13597566.2015.1043995.

Sztompka, P. (2012). Socjologia. Analiza społeczeństwa. Kraków: Znak.

Terlouw, K. (2009). Re-scaling regional identities: Communicating thick and thin regional identities. Studies in Ethnicity and Nationalism, 9(3), 452-464. DOI: 10.1111/j.1754-9469.2009.01064.x.

Wong Villanueva, J. L., Kidokoro, T., Fumihiko, S. (2020). Cross-Border Integration, Cooperation and Governance: A Systems Approach for Evaluating "Good" 
Governance in Cross-Border Regions. Journal of Borderlands Studies, 1-24. DOI: $10.1080 / 08865655.2020 .1855227$.

Veemaa, J. (2012). Internationalizing the Spatial Identity of Cross-Border Cooperation. European Planning Studies, 20(10), 1647-1666, DOI: 10.1080/09654313.2012.713335. World Bank Database (2019). GDP per capita, PPP (current international \$). Pobrane z: https://data.worldbank.org/indicator/NY.GDP.PCAP.PP.CD.

Zimmerbauer, K. (2011). From image to identity: Building regions by place promotions. European Planning Studies, 19(2), 243-260. DOI: 10.1080/09654313.2011.532667.

Ziółkowski, M. (1989). Wiedza, jednostka, społeczeństwo: zarys koncepcji socjologii wiedzy. Warszawa: PWN. 